\title{
A Behavioral Interpretation of the NAV Discount Puzzle in Listed Real Estate Companies
}

\author{
Sally Monson, Helen X. H. Bao ${ }^{1}$ and Colin Lizieri \\ Department of Land Economy, University of Cambridge, CB39EP, Cambridge, UK
}

\section{Executive Summary:}

The NAV discount is a long standing puzzle in the listed real estate context. In this paper we extend the existing literature's rational and noise trader explanations by exploring the influence of specific irrational behaviors. Based on behavioral biases identified in the stock and real estate markets, we hypothesize the existence of a relationship between lagged NAV growth and the NAV discount. The findings provide initial evidence of trendchasing behavior between the dual real estate markets. The results have broader implications for the perception of the relationship between public and private real estate markets.

${ }^{1}$ Corresponding author ( $\underline{\text { hxb20@cam.ac.uk)}) . ~}$ 


\title{
A Behavioral Interpretation of the NAV Discount Puzzle
}

\author{
in Listed Real Estate Companies
}

\section{Introduction}

The net asset value (NAV) discount is not just an academic puzzle. Persistent differences between public and private market valuations influence decisions to privatise listed real estate companies. Understanding the NAV discount puzzle is also crucial for investment strategies attempting to time the market. Yet, despite the importance of the topic, existing research is unable to fully account for the NAV discount puzzle (See, for example, Pattitoni, Petracci, \& Spisni, 2013).

The majority of existing NAV discount studies assumes that the public market is more efficient than the private market. The price/information transmission mechanism literature largely emphasises the process from public to private markets (see, for example, Gyourko \& Keim, 1992; Yavas \& Yildirim, 2011). The perspective is reflected in the development of so-called 'pure property' indices, which attempt to use the valuation of REIT shares to uncover real time valuation of the underlying property (Geltner, 2015). Nonetheless, it does not necessarily rule out a relationship in the opposite direction. Some recent studies suggest the possibility of a two-way interaction between the public and private real estate market. For example, real estate investment decisions by institutional investors are found to be affected by the sentiment of private real estate investors in the US market (Das, Freybote, \& Marcato, 2015; Freybote \& Seagraves, 2017). There seems to be a sentiment spill-over between the private and public real estate markets. Specifically, the release of a series of good NAV figures, if interpreted as positive REIT sentiment by institutional investors, may drive institution REIT investments. This may lead public market participants to overact to their perceived trend in the private market.

Following this line of research, we adopt a broader perspective than the traditional account of information transmission in NAV discount studies. We develop a framework that allows the public market to lag behind the private market. This is achieved by considering the characteristics of the real estate market from a behavioral perspective and drawing on the relevant findings from the stock market. Recently, behavioral approaches have become increasingly popular in a variety of research disciplines. However, the potential contribution of such an approach to the NAV discount puzzle in listed real estate companies remains unexplored. The peculiarities of real estate are widely acknowledged to affect the efficiency of the market and its susceptibility to irrational behaviour (Bao \& Li, 2016; Bao \& Meng, 2017; Wang \& Hui, 2017). Within this context, a behavioral perspective emerges as a natural extension to existing explanations for the NAV discount puzzle. 
We derive hypotheses that demonstrate the extension from the general ideas of rational and noise trader models, towards the more focused approach adopted in this study. The formulation of the hypotheses, specifically based on what is known about particular behaviors in the real estate context, is hoped to be able to provide the additional detail necessary to accommodate the unexplained variation in the NAV discount. The hypotheses also imply an alternative direction of causality between the public and private real estate markets to the traditional public-to-private assumption. Support for the hypotheses could potentially have broader implications for conceptualising the relationship between the public and private market. The hypotheses are tested by a behavioural extension of the model in Clayton and MacKinnon (2002). Using UK real estate market data between 2002 and 2017, we find general support to our hypotheses. Our analysis suggests causality from information in private real estate market to public real estate market.

The remainder of this paper sets out the investigation and discusses the results in more detail. Section 2 introduces the existing literature on the NAV discount debate. Section 3 considers the relevance of the behavioral perspective and justifies the selection of specific behavioral explanations as the hypotheses to be tested. The econometric methods adopted and the data employed are discussed in Section 4, followed by the presentation and discussion of results in Sections 5 and 6. Section 7 concludes.

\section{Literature Review}

Attempts to explain the NAV discount in both financial asset and real estate markets can be organised into two schools of thought; the 'rational' approach and the 'noise trader' approach.

\section{Rational Explanations}

The rational approach attempts to explain the NAV discount by reference to the different characteristics of direct and indirect investment (Cherkes, Sagi, \& Stanton, 2009; Malkiel, 1995). According to traditional discounted cash flow methodology, the different prices recorded in the public and private market reflect differences in the level and risk of cash flows investors expect to receive. For instance, greater liquidity in the public market over the private market, and the consequent reduction in liquidity risk premium, is hypothesised to increase the value of indirect investment (Benveniste, Capozza, \& Seguin, 2001; Cheung, Chung, \& Fung, 2015). This approach also argues that firm-level differences can influence the NAV discount. For example, high management fees may be interpreted as a principal-agent problem, leading firms with high management fees to have larger discounts (Capozza \& Korean, 1995; Lenkey, 2015).

Barkham and Ward (1999) investigate a comprehensive set of rational hypotheses for listed property discounts for UK property companies, including the effect on the NAV discount from management expenses, leverage, inside ownership, outstanding tax burden, size, and firm reputation. They find strong evidence that the NAV discount becomes more negative with increasing tax liability. The result is explained on the basis that taxes represent the state's claim on the firm's assets, diminishing the value retrievable by investors. They also find support for the hypothesis that increased 
leverage is associated with more negative NAV discounts, which is explained in terms of increased equity risk. Similar results are found in other research (Clayton \& MacKinnon, 2001; Morri, McAllister, \& Ward, 2005).

Despite the clear intuition and evidence for specific rational hypotheses, there are several flaws with the approach. Particular criticism has focused on the methodology employed in the tests and the narrow emphasis on individual hypotheses. Many studies fail to explain each factor's relative strength and the complex interrelationship with other factors (Rehkugler, Schindler, \& Zajonz, 2012). The lack of stability in the results generated by alternative specifications supports the view that conclusions from incomplete models are likely to be misleading (Morri et al., 2005). A further problem for the rational approach arises from the identification of a significant market NAV discount variable. Morri et al. (2005) highlight that while firm-level NAV deviations are explained by market NAV deviation, there is no explanation for the cause of the common NAV deviation.

The methodological issues are compounded by the inconclusive explanations that can be invoked to account for the findings. For several variables, there is no clear direction that the rational hypothesis should take. Depending on the researcher's perspective, it is possible to argue that it is rational for a particular characteristic to either increase or decrease the NAV discount. For instance, on the one hand, management expenses can be viewed as a proxy for managerial ability, which indicates a smaller, less negative, NAV discount; on the other hand, expenses can be viewed as additional fee associated with indirect investment and potentially a source of agency costs, which leads to a larger, more negative, NAV discount. Similarly, Brounen and Laak (2005) and Clayton and MacKinnon (2001) identify a negative relationship between firm size and the NAV discount, attributing the finding to greater access to capital and investment opportunities. However, Barkham and Ward (1999) and Bond and Shilling (2003) find evidence of the opposite relationship, arguing instead that this represents greater liquidity costs arising from the distortion in market supply on asset liquidation. Interpretations risk being chosen ex-post to fit findings.

\section{Noise Trader Explanations}

The rational approach has been challenged by an alternative perspective, emphasising the role of sentiment. This is based on a closed-end fund application of the noise trader model from De Long, Shleifer, Summers, and Waldmann (1990). The model assumes two types of traders exist: rational and noise traders. Other critical assumptions include: (1) noise trader sentiment is unpredictable; (2) rational investors have relatively short time horizons; (3) noise trader sentiment is systematic. The model predicts that prices diverge from fundamental values, with NAV discounts reflecting additional noise trader risk.

Investigations employing a variety of methodologies have generated support for the role of sentiment in asset pricing and the NAV discount (See, for example, Baker \& Wurgler, 2006; C. M. C. Lee, A. Shleifer, \& R. H. Thaler, 1991). As early literature identified high correlations between returns on real estate funds and small-cap stocks (Glascock, Lu, \& So, 2000), and based on the assumption that individual investors dominate the small-cap stock market, one may expect that the sentiment of individual investors is driving the 
performance of real estate investments. Later real estate research has directly incorporated a proxy for investor sentiment into the NAV discount model. For example, Barkham and Ward (1999) employ the CBI industrial confidence index and the MMI inflation expectations, and identify a significant role of sentiment in the UK. Morri and Baccarin (2016) provide further evidence for the 'noise trader' hypothesis by introducing an appraisal reduction coefficient as the measurement of sentiment in their models.

While mainstream economics in general has relaxed the restrictive assumptions of rationality, the noise trader explanation has been criticised on the basis of its treatment of irrationality (Ramiah, Xu, \& Moosa, 2015). In C. Lee, A. Shleifer, and R. H. Thaler (1991), individual investors are assumed to generate the noisy fluctuations that lead to NAV discounts. However, this has been challenged by a number of other studies. Chen, Kan, and Miller (1993) provide an initial critique, identifying instability in the relationship between the closed-end fund discount and ownership structure, and concluding that the findings of C. Lee et al. (1991) cannot be generalised. Elton, Gruber, and Busse (1998) also dispute the idea that the existence of discounts can be attributed to additional risk from noise traders. The authors find that the influence of the proxy for sentiment is not significantly different across the portfolio categories, and that sentiment is not behind the price behavior of closed-end funds.

In addition to the evidence against the noise trader hypothesis in general, its application to the real estate market appears to be especially vulnerable to criticism. The peculiarities of real estate, particularly in relation to the operational burdens, means that it is common to outsource real estate expertise, even for institutional investors. Institutional ownership of US equity REITs increased from $14.14 \%$ in 1990 to $75.19 \%$ in 2011 (An, Wu, $\& \mathrm{Wu}, 2015)$. Thus, it is not clear whether the players in the market can be expected to show the purported irrationality.

From surveying the literature, it is apparent that neither the rational nor noise trader approaches are infallible, nor are they capable of fully accounting for the puzzling existence of the NAV discount. In this paper, we bridge this gap in the literature by adopting a nuanced perspective of market participants' irrational behaviors to account for the market-wide NAV discount movements that currently remain unexplained.

\section{Theoretical Framework and Testable Hypotheses}

The noise trader approach represents an initial application of behavioral ideas in explanations for the NAV discount puzzle. However, while the approach relaxes the assumption of perfect rationality, it is limited to measurement of noise trading only. Contrasting with the reliance on a single catch-all sentiment measure, the behavioral literature outside the NAV discount debate emphasises not only the tendency to be affected by sentiment, but also why this occurs and how this impacts behavior (Tversky \& Kahneman, 1974). A variety of specific biases and heuristics have been identified, including, inter alia, loss aversion, availability bias, optimism bias, anchoring effect, conservatism and representativeness bias. A disaggregate approach, focusing on specific biases, has the potential to provide a better understanding of the mechanisms behind the NAV discount. In this section we derive hypotheses by considering the characteristics of 
the real estate market from a behavioral perspective and drawing on the relevant formal theories from the stock market behavioral literature.

According to the weak form of the Efficient Market Hypothesis, past performance should not be able to predict future performance. However, investment strategies based on historical performance and fundamental data have identified profitable opportunities in the market. For example, De Bondt and Thaler (1985) use stocks from the top and bottom decile of preceding three-year performance to form 'winner' and 'loser' portfolios respectively, and identify substantial positive returns from the 'loser' strategy. This indicates market overreaction to past trends and a subsequent reversal. Jegadeesh and Titman (1993) further explore the short-term momentum effect by constructing portfolios based on stocks' past six-month performance. They find that the 'winner' portfolio outperforms the 'loser' portfolio over the next six-months. On the other hand, there is evidence to suggest that the market exhibits underreaction to isolated corporate events (Bernard \& Thomas, 1990; Ikenberry \& Ramnath, 2002; Kadiyala \& Rau, 2004). Several traits identified in psychological studies also support the existence of underreaction. For instance, anchoring bias refers to the tendency for agents to adjust their beliefs only marginally from expectations in the prior period. Chen et al. (1993) find evidence for anchoring in the incorporation of information into stock market analyst forecasts, with forecasts adjusting slowly despite the provision of new information.

Theoretical contributions have sought to accommodate the empirical findings which suggest the co-existence of over and underreaction. Daniel, Hirshleifer, and Subrahmanyam (1998) provide an explanation based upon investor overconfidence and biased self-attribution. Short term momentum is driven primarily from overreaction to short term information (the result of overconfidence) and trends (the result of selfattribution bias). Barberis, Shleifer, and Vishny (1998) offer an alternative explanation based upon representativeness (trend following) and conservatism (mean-reversion). In the model, investors are uncertain which 'regime' - trend or mean-reversion - is in operation at any point in time, and players' beliefs regarding the prevailing regime are influenced by past experience. To the extent that the investor considers that the mean reverting regime applies, they underreact to information. Alternatively, belief in the trending regime means that they overact to information (Shefrin, 2013).

Further nuances have been identified in relation to the symmetry of responses to positive and negative trends. Easterwood and Nutt (1999) find evidence of generalised optimism, which is a tendency for overreaction to be greater when responding to good news. In the context of trend extrapolation, generalised optimism suggests that past rising trends may trigger greater overreaction than past falling trends. Additional research has also considered the nature of the information itself. Daniel and Titman (2006) argue that linking over extrapolation to overconfidence implies an emphasis on 'soft' information as opposed to fundamental information.

Based on these findings from the stock market context, it remains to be investigated whether analogous under and overreaction behavior can provide the missing piece in the explanations for the NAV discount puzzle in real estate sector. The complexity of decisionmaking in the real estate context and the demands placed on investor cognition may lead 
to the adoption of effort-saving heuristics and biases (Geltner, G., Clayton, \& Eichholtz, 2013). In this already convoluted context, the rise of Big Data has generated yet more information for investors to absorb. It follows that research into the concept of salience has become particularly relevant (Andreassen, 1990; Brown \& Matysiak, 2000; Jandl, 2015). A range of factors have been considered to affect the salience of information, including inter alia, timing, presentation, and availability of alternatives (Andreassen, 1990; Bordalo, Gennaioli, \& Shleifer, 2015). A compelling result for the real estate context concerns the effect of perceived trends (Andreassen \& Kraus, 1990). Evidence of the association between salience and trends already exists in a variety of real estate settings. Cities which have experienced rapid house price increases in the past are found to be associated with higher expectations of future house price rises than is expected elsewhere (Case \& Shiller, 1988). Evidence from the real estate development industry indicates that even professionals in the real estate market may be enticed by trends and exhibit habit persistence (Antwi \& Henneberry, 1995).

In a further extension, it is suggested that trends accompanied by an explanation for the trend are more prone to generate anti-regressive behavior (Wameryd, 2001). In particular, there is evidence to support the media's role in influencing the market via the dissemination of explanations and beliefs regarding investment performance (Tetlock, 2007). Given the fundamental importance of the property market to the economy, and the media attention it attracts, this appears to raise the possibility of trend following behavior in the real estate market. There are empirical evidence from real estate markets to support such a notion (See, for example, DeCoster \& Strange, 2012).

Focusing on the public market response to fundamental information from the private market, we hypothesise a relationship between NAV growth and NAV discount, whereby trend following behavior in relation to past NAV growth influences the current NAV discount. It is noted that while NAV growth could be regarded as a fundamental accounting measure, thus falling foul of the tangible/intangible distinction raised by Daniel and Titman (2006), the imprecise nature of NAV estimates distinguishes the variable from other fundamentals. Consequently, there is arguably a greater opportunity for investor interpretation and biases to be introduced. Our hypotheses are as follows:

Hypothesis I: Market underreaction to isolated NAV changes. This will lead to movement in the NAV discount in the opposite direction to the growth in NAV. Positive (negative) past NAV growth will not generate sufficiently positive (negative) changes in share price and will lead to more (less) negative NAV discounts.

Hypothesis II: Market overreaction to runs of high NAV growth. This will lead to movement in the NAV discount in the same direction as growth in NAV. Runs of past NAV growth will generate excessively positive changes in share price and will lead to less negative NAV discounts. 


\section{Data and Methods}

The framework adopted is based on the market NAV discount model developed by Clayton and MacKinnon (2002), which expresses the NAV discount as a linear function of three variables: present value of growth opportunities, liquidity, and sentiment.

$N A V$ Discount $=c+\beta_{1}($ growth opportunities $)+\beta_{2}$ (liquidity $)+\beta_{3}($ sentiment $)+e_{t}$

The growth opportunities and liquidity variables represent the rational explanations for the NAV discount at the market level (Rational Explanations). The variables reflect that according to the rational approach, cash flows from public real estate can be distinguished from private real estate on the basis of shares being freely tradable (i.e. liquidity variable) and the potential value added by the skills and market power of listed real estate companies (i.e. growth opportunities variable). The sentiment variable represents the noise trader hypothesis (Noise Trader Explanations).

In the estimation of the model, Clayton and MacKinnon (2002) adopt a market-wide approach in order to avoid the issues with the early firm-level investigations. The infrequency of appraisals is the primary limitation of the firm-level approach. Capozza and Korean (2009) attempt to overcome this constraint by using a weighted capitalisation rate to capitalise property income. However, their weightings are determined according to average property value in the metropolitan area for each asset, which fails to take into account property idiosyncrasies and results in a loss of precision. The use of a market-wide NAV index provides an alternative method to mitigate the infrequency of appraisals as it incorporates a wider distribution of appraisal dates from all firms in the market.

An additional advantage of adopting a market-wide perspective is the reduction in appraiser error. While, for example, the RICS Red Book provides guidance for UK valuers, the guide is largely procedural and there remains scope for errors in appraisal inputs (Barkham \& Ward, 1999). A market-level approach enables a reduction in unsystematic error, in addition to reducing systematic error from individual appraiser's biases of valuing too high/low (Geltner, 1993; Liow, 1996). It is also possible to justify the marketlevel perspective from the finding that the NAV discount is a market-wide phenomenon and the market discount is a significant explanatory factor in firm-level estimations (Morri et al., 2005).

Despite the benefits of a market-wide approach, there is a notable absence of marketlevel investigations into the NAV discount for the UK market despite its size and significance in the global listed real estate universe. In order to redress this research deficiency, this paper's behavioral extension of the Clayton and MacKinnon (2002) framework is conducted using UK data for the period from May 2002 to March $2017^{2}$. Table 1 gives data sources, variable definitions, and descriptive statistics of our data.

\footnotetext{
${ }^{2}$ Although EPRA's NAV discount data is available from 1989, the data for Equity Offerings has zero values between February and April in 2002. Subsequently, we treat these zero values as outliers and the sampling period starts from May 2002 for the sake of consistency.
} 
The FTSE EPRA/NAREIT UK Index provides the monthly NAV discount data for the UK listed market (NAVD). We performed Unit Root test (i.e., ADF and PP tests) to check series stationarity. The results suggest that NAVD is stationary in our sampling period. We include two measurements as the Rational Explanations variables. Growth opportunities in the public market are approximated using the market value of equity offerings (EQ). The liquidity variable is derived from private market transaction volume data (TRANS) collected by HMRC. The sentiment variable representing the Noise Trader Explanations is captured by an Business Confidence Index (BCI) for the UK market.

To test Hypothesis I, we include a lagged term of NAV growth (NAVG) to capture the effect of past NAV growth on NAV discount. To test Hypothesis II, we introduce a dummy variable ABOVE to indicate the presence of a series of above average NAV growth, and then create interaction terms between ABOVE and NAVG to test for evidence of overreaction to growth information following a run of high growth.

We also included a range of control variables. Specifically, to investigate the pure effect of NAV growth on NAV discount, it is necessary to control for public market performance. A common practice in the literature is to use past return to represent market performance (e.g. Daniel and Titman, 2006). We follow the convention by using the lagged return rate of the EPRA/NAREIT index (REIT) to controls for past public market performance. We also include interest rate (INT), GDP growth (GDP), and monthly return rate of FTSE (FTSE) are included to control for macroeconomic influences.

We run a Pairwise Granger Causality Test between NAV discount and NAV growth to check the presence and nature of causality between NAV discount and NAV growth. The test results suggest a bi-directional causality between the series, and consequently a vector autoregression (VAR) specification. The VAR approach provides the appropriate framework for accommodating statistical complexity and feedback effects, without the informational demands of a long-term structural model (Li, Mooradian, \& Yang, 2009).

Before estimating the econometric model, some initial investigations provide general evidence in support of the hypotheses. Figure 1 shows the evolution of the NAV discount and NAV growth series over the sampling period. The co-movement of the two series in the time series plot is indicative of a relationship between the variables. . Stationarity tests identify both the NAV discount and NAV growth series as I(0), leading to the rejection of co-integration between the variables. 
Figure 1. NAV discount and NAV growth (May 2002 - March 2017)

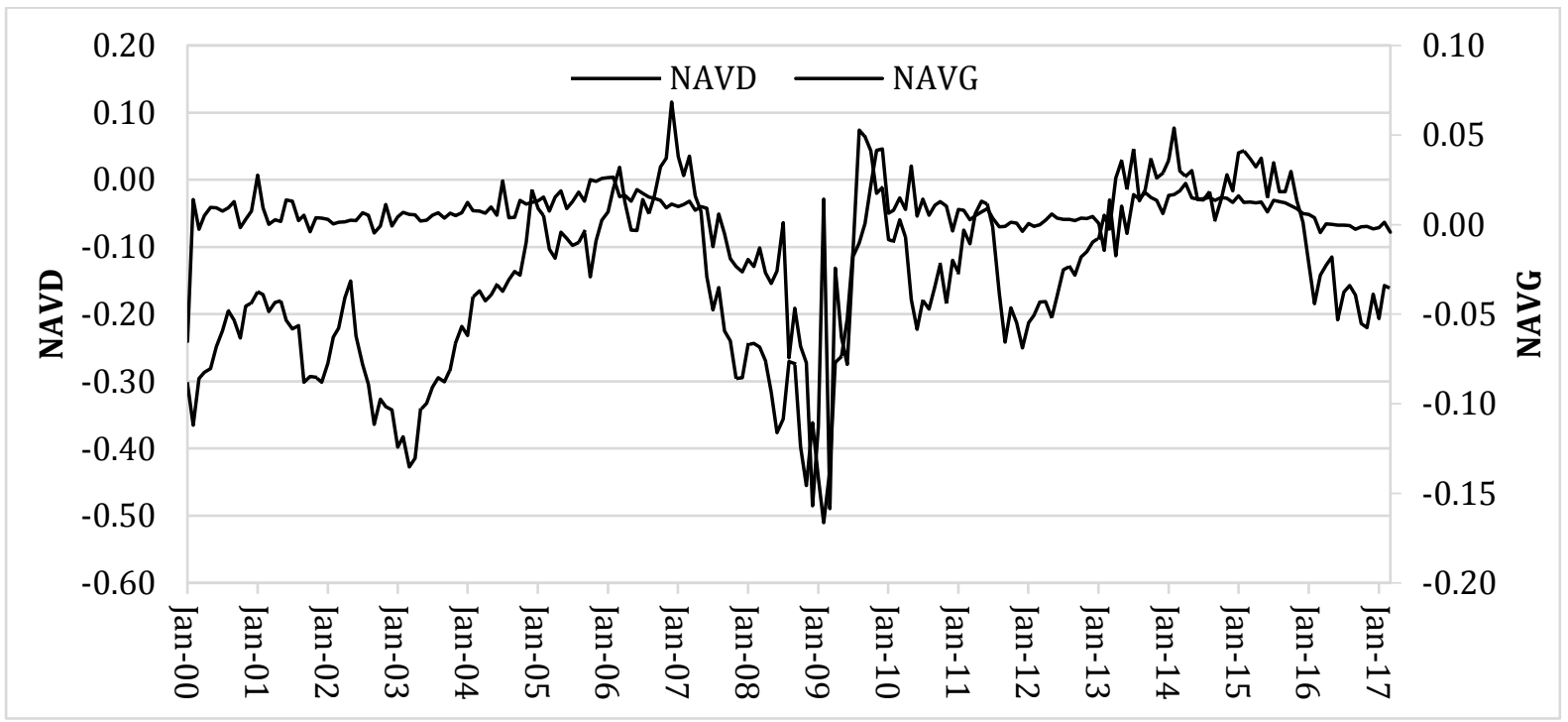


Table 1. Data Source, Variable Definitions, and Descriptive Statistics

\begin{tabular}{|c|c|c|c|c|c|c|c|c|}
\hline & Variable/Proxy & $\begin{array}{c}\text { Var. } \\
\text { Name } \\
\end{array}$ & Definitions & Data Sources & Mean & SD & Min & Max \\
\hline $\begin{array}{l}\dot{\pi} \\
\dot{0} \\
\dot{0}\end{array}$ & NAV discount & NAVD & $\begin{array}{l}\text { Percentage difference between NAV and stock market } \\
\text { index valuation } \\
\text { (Share price / NAV per share) - } 1 \\
\text { (monthly) }\end{array}$ & $\begin{array}{l}\text { FTSE } \\
\text { EPRA/NAREIT UK }\end{array}$ & -0.1505 & 0.1264 & -0.5103 & 0.1158 \\
\hline \multirow{2}{*}{ 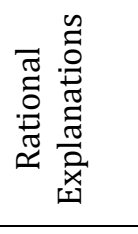 } & $\begin{array}{l}\text { Monthly equity } \\
\text { offering }\end{array}$ & EQ & $\begin{array}{l}\text { Monthly GBP worth of real estate equity offerings } \\
\text { (monthly) (million) }\end{array}$ & SNL & 199.3789 & 350.8344 & 0.0000 & 2210.867 \\
\hline & $\begin{array}{l}\text { Change in } \\
\text { property } \\
\text { transaction }\end{array}$ & TRANS & $\begin{array}{l}\text { Number of non-residential property transactions } \\
\text { (monthly) (first differenced) }\end{array}$ & HMRC & 0.0005 & 0.1379 & -0.3510 & 0.4206 \\
\hline 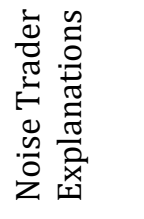 & $\begin{array}{l}\text { Business } \\
\text { Confidence }\end{array}$ & $\mathrm{BCI}$ & $\begin{array}{l}\text { Index of business confidence ( monthly, long term } \\
\text { average }=1 \text { ) }\end{array}$ & OECD & 1.0011 & 0.0113 & 0.9606 & 1.0190 \\
\hline \multirow{2}{*}{ 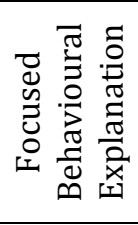 } & $\begin{array}{l}\text { Monthly NAV } \\
\text { growth }\end{array}$ & NAVG & Monthly growth rate of NAV (monthly) & $\begin{array}{l}\text { FTSE } \\
\text { EPRA/NAREIT UK }\end{array}$ & 0.0017 & 0.0248 & -0.1586 & 0.0422 \\
\hline & $\begin{array}{l}\text { Run of above } \\
\text { average NAV } \\
\text { growth }\end{array}$ & ABOVE & $\begin{array}{l}=1 \text { if two immediately prior months record above } \\
\text { average NAV growth, and } 0 \text { otherwise }\end{array}$ & $\begin{array}{l}\text { FTSE } \\
\text { EPRA/NAREIT UK }\end{array}$ & 0.6232 & 0.4858 & 0.0000 & 1.0000 \\
\hline \multirow{4}{*}{ 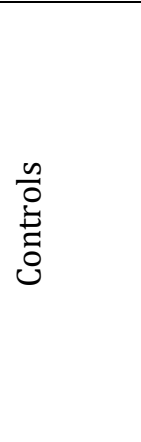 } & $\begin{array}{l}\text { Monthly } \\
\text { FTSE/NAREIT } \\
\text { return }\end{array}$ & REIT & Monthly return on FTSE/NAREIT UK index (monthly) & $\begin{array}{l}\text { FTSE } \\
\text { EPRA/NAREIT UK }\end{array}$ & 0.0026 & 0.0597 & -0.2889 & 0.2222 \\
\hline & Interest rate & INT & Gross redemption yields on 10 year gilts (monthly) & Bank of England & 0.0367 & 0.0134 & 0.0067 & 0.0580 \\
\hline & $\begin{array}{l}\text { Annual GDP } \\
\text { growth }\end{array}$ & GDP & $\begin{array}{l}\text { Growth rate of GDP ( } 2016 \text { prices, interpolated into } \\
\text { monthly data) }\end{array}$ & $\begin{array}{l}\text { Office of National } \\
\text { Statistics }\end{array}$ & 0.0014 & 0.0022 & -0.0094 & 0.0076 \\
\hline & $\begin{array}{l}\text { Monthly FTSE } \\
\text { return }\end{array}$ & FTSE & Monthly return on FTSE 100 index (monthly) & SNL & 0.0003 & 0.0403 & -0.1395 & 0.0830 \\
\hline
\end{tabular}




\section{Empirical Findings}

We use the following specification in Clayton and MacKinnon (2002) with an AR(1) term of NAVD as the benchmark model (labelled as Model 0).

$$
\begin{aligned}
N A V D_{t}=\beta_{0}+ & \beta_{1} N A V D_{t-1}+\beta_{2} E Q_{t}+\beta_{3} T_{R A N S_{t}}+\beta_{4} B C I_{t}+\beta_{5} I N T_{t}+\beta_{6} F_{T S E} \\
& +\beta_{7} G D P_{t}+\varepsilon_{t}
\end{aligned}
$$

Coefficient estimates of Model 0 are given in Table 2. The significant coefficient loading for NAVD $(-1)$ indicate a positive serial autocorrelation in the movement of NAVD. There are weak evidences to support the Rational Explanations and the Noise Trader Explanations. Specifically, both TRANS and BIC are not significant at the 5\% level. These results serve to highlight the inadequacies of the two existing explanations.

Table 2. Estimation Results of Model 0 (Dependent variable: NAVD)

\begin{tabular}{lcccc}
\hline Variable & Coefficient & Std. Err. & t-Statistic & Prob. \\
\hline NAVD(-1) & 0.9200 & 0.0279 & 32.9796 & 0.0000 \\
EQ & $1.58 \mathrm{E}-05$ & $8.14 \mathrm{E}-06$ & 1.9464 & 0.0532 \\
TRANS & 0.0089 & 0.0194 & 0.4610 & 0.6454 \\
BCI & -0.0758 & 0.2973 & -0.2551 & 0.7990 \\
INT & -0.2226 & 0.2216 & -1.0045 & 0.3165 \\
FTSE & 0.6761 & 0.0719 & 9.4014 & 0.0000 \\
GDP & -0.8570 & 1.3244 & -0.6471 & 0.5184 \\
C & 0.0690 & 0.3007 & 0.2295 & 0.8187 \\
\hline$R^{2}$ & 0.9231 & & Durbin-Watson stat & 1.9439 \\
Adjusted $R^{2}$ & 0.9200 & & White test: F-stat & 1.7265 \\
F-stat & 293.3373 & & Prob(F-stat) & 0.0138 \\
Prob(F-stat) & 0.0000 & & & \\
\hline
\end{tabular}

\section{Baseline VAR Model (Model 1)}

Our first improvement to the benchmark model is an initial VAR model specification, which extends the variables used by Clayton and MacKinnon (2002) to include lagged NAV growth and the reaction to series of above average NAV growth, in a form that reflects the potential feedback relationships between the public and private markets.

$$
\begin{aligned}
{\left[\begin{array}{l}
N A V D_{t} \\
N A V G_{t}
\end{array}\right]=\left[\begin{array}{l}
c_{D} \\
c_{G}
\end{array}\right]+\left[\begin{array}{ll}
A_{D, D} & A_{D, C} \\
A_{G . D} & A_{G, C}
\end{array}\right]\left[\begin{array}{l}
N A V D_{t-1} \\
N A V G_{t-1}
\end{array}\right]++\left[\begin{array}{l}
\beta_{D, 1} \\
\beta_{G, 1}
\end{array}\right]\left[\text { ABOVE*NAVG } G_{t-1}\right]+\left[\begin{array}{l}
\beta_{D, 2} \\
\beta_{G, 2}
\end{array}\right][E Q] } \\
+\left[\begin{array}{l}
\beta_{D, 3} \\
\beta_{G, 3}
\end{array}\right][\text { TRANS }]+\left[\begin{array}{l}
\beta_{D, 4} \\
\beta_{G, 4}
\end{array}\right][B C I]+\left[\begin{array}{l}
\beta_{D, 5} \\
\beta_{G, 5}
\end{array}\right][I N T]+\left[\begin{array}{l}
\beta_{D, 6} \\
\beta_{G, 6}
\end{array}\right][F T S E] \\
+\left[\begin{array}{l}
\beta_{D, 7} \\
\beta_{G, 7}
\end{array}\right][G D P]+\left[\begin{array}{l}
\beta_{D, 8} \\
\beta_{G, 8}
\end{array}\right]\left[\text { REIT }_{t-1}\right]+\left[\begin{array}{l}
e_{D, t} \\
e_{G, t}
\end{array}\right]
\end{aligned}
$$


We labelled this model as Model 1 and present the estimation results in the second column of Table 3. The lagged NAV growth variable $\left(\mathrm{NAVD}_{\mathrm{t}-1}\right)$ is included to test Hypothesis I, and the interaction term (ABOVE $* \mathrm{NAVG}_{\mathrm{t}-1}$ ) for the test of Hypothesis II. The coefficients for both variables show the hypothesised sign. However, neither term is significant. In addition, despite a high $R^{2}$, residual plots reveal a poor fit of the model during the middle portion of the sample period, seemingly coinciding with the Global Financial Crisis (see Figure 2). We subsequently modify the specification of Model 1 to incorporate this factor.

\section{Figure 2. NAVD and NAVG Residuals from Model 1}
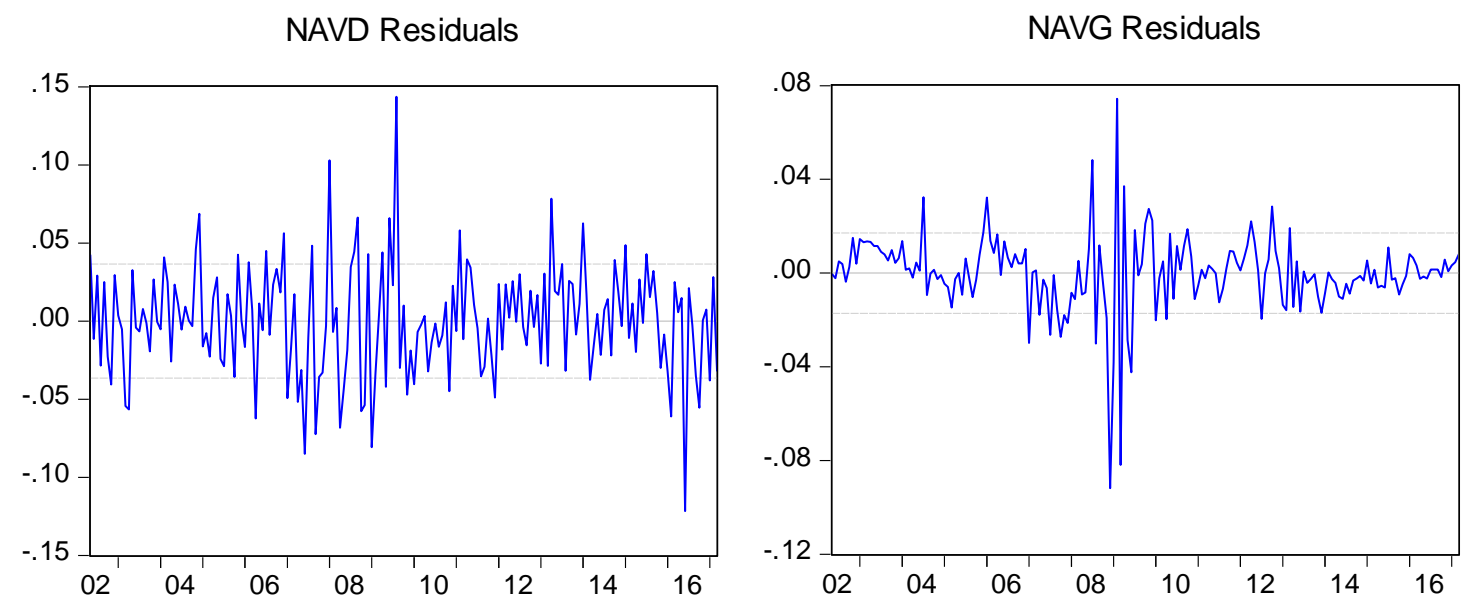

\section{VAR with Crisis Indicator (Model 2)}

Based on a visual inspection of the data (Figure 1) and residuals (Figure 2), a dummy variable CRISIS is defined for the Global Financial Crisis period from January 2007 to April 2009. Interaction terms with CRISIS are also included in Model 2 to allow for different responses to NAV growth during this period. The estimation results of this model can be found in the third column in Table 3 .

The negative coefficient for the lagged NAV growth variable in the estimation of Model 2 indicates underreaction; the model predicts a larger NAV discount (i.e. more negative) following an increase in NAV, which is interpreted as reflecting an increased divergence between the public and private valuations due to a subdued response in the stock market valuation. In contrast, the interaction term $A B O V E * N A V G_{t-1}$, which represents the marginal response to NAV growth information following a series of above average growth, displays a positive coefficient. This weakly significant coefficient implies that the model predicts overreaction to information following a perceived pattern in earlier growth. These findings provide support for Hypothesis I and Hypothesis II respectively. Furthermore, the total effect of NAV growth on NAV discount when two previous growths are above average is estimated to be positive (i.e., the overall effect is $0.9121-0.8013=$ 0.1108). 
Table 3. Estimation Results of Models 1 - 4

\begin{tabular}{|c|c|c|c|c|c|c|c|c|}
\hline \multirow[b]{2}{*}{ Variable } & \multicolumn{2}{|c|}{ Model 1} & \multicolumn{2}{|c|}{ Model 2} & \multicolumn{2}{|c|}{ Model 3} & \multicolumn{2}{|c|}{ Model 4} \\
\hline & NAVD & NAVG & NAVD & NAVG & NAVD & NAVG & NAVD & NAVG \\
\hline \multirow{2}{*}{ NAVD(-1) } & $0.8898^{a}$ & $0.0634^{a}$ & $0.9075^{a}$ & $0.0748^{a}$ & 0.9049 a & $0.0786^{a}$ & $0.9126^{a}$ & 0.0749 a \\
\hline & [25.7794] & [3.5878] & [25.7641] & [4.0765] & [25.44] & [4.3411] & [25.3636] & [4.1423] \\
\hline \multirow{2}{*}{ NAVG(-1) } & -0.1881 & $0.1873^{b}$ & $-0.8013 b$ & $0.3338^{c}$ & -0.1645 & 0.2116 & -0.1552 & 0.1818 \\
\hline & {$[-1.1458]$} & [2.2286] & {$[-2.2737]$} & [1.8183] & {$[-0.1856]$} & [0.4688] & {$[-0.1751]$} & [0.4084] \\
\hline \multirow{2}{*}{$\begin{array}{l}\text { ABOVE* } \\
\text { NAVG(-1) }\end{array}$} & 0.4325 & 0.3469 & 0.9121 & 0.1156 & 0.3524 & 0.2282 & 0.5432 & -0.1367 \\
\hline & [0.9401] & [1.4732] & [1.6069] & [0.3910] & [0.3855] & [0.4900] & [0.5608] & {$[-0.2809]$} \\
\hline \multirow{2}{*}{$\begin{array}{l}\text { CRISIS* } \\
\text { NAVG(-1) }\end{array}$} & & & $0.6817 \mathrm{c}$ & -0.1826 & -0.4019 & -0.3904 & -0.3785 & -0.4056 \\
\hline & & & [1.8667] & {$[-0.9599]$} & {$[-0.4357]$} & {$[-0.8309]$} & {$[-0.4105]$} & {$[-0.8758]$} \\
\hline \multirow{2}{*}{$\begin{array}{l}\text { CRISIS * } \\
\text { ABOVE* } \\
\text { NAVG(-1) }\end{array}$} & & & $-4.6141^{a}$ & -1.2846 & $-3.4850^{c}$ & -1.0930 & $-3.3270^{b}$ & -1.1937 \\
\hline & & & {$[-2.9776]$} & {$[-1.5914]$} & {$[-1.9586]$} & {$[-1.2062]$} & {$[-1.8674]$} & {$[-1.3341]$} \\
\hline \multirow{2}{*}{$\begin{array}{l}\text { BELOW* } \\
\text { NAVG(-1) }\end{array}$} & & & & & -0.7947 & 0.1341 & -0.7065 & 0.0545 \\
\hline & & & & & {$[-0.8001]$} & {$[0.2651]$} & {$[-0.7102]$} & [0.1091] \\
\hline \multirow{6}{*}{$\begin{array}{l}\text { CRISIS * } \\
\text { BELOW* } \\
\text { NAVG(-1) } \\
\text { OPT* } \\
\text { BELOW* } \\
\text { NAVG(-1) } \\
\text { PESS* } \\
\text { ABOVE* } \\
\text { NAVG(-1) }\end{array}$} & & & & & 1.5275 & 0.4421 & 1.4737 & 0.5042 \\
\hline & & & & & [1.4982] & [0.8514] & [1.4445] & [0.9841] \\
\hline & & & & & & & -1.4386 & 0.8863 \\
\hline & & & & & & & {$[-1.4597]$} & [1.7905] \\
\hline & & & & & & & -0.2795 & $0.6762 \mathrm{~b}$ \\
\hline & & & & & & & {$[-0.4386]$} & [2.1125] \\
\hline \multirow{2}{*}{ EQ } & $1.3 \mathrm{e}-8^{b}$ & $-6.8 e-9 b$ & $1.5 \mathrm{e}-8^{\mathrm{a}}$ & $-5.9 e-9 c$ & $1.3 e-8^{b}$ & $-7.5 e-9$ a & $1.2 \mathrm{e}-8^{c}$ & $-6.2 e-9 b$ \\
\hline & [2.0865] & {$[-2.1413]$} & [2.4315] & {$[-1.8668]$} & [2.0888] & {$[-2.4338]$} & [1.873] & {$[-2.0017]$} \\
\hline \multirow{2}{*}{ TRANS } & 0.0098 & -0.0053 & 0.0021 & -0.0044 & 0.0049 & -0.0030 & 0.0053 & -0.0019 \\
\hline & [0.4768] & {$[-0.503]$} & [0.1045] & {$[-0.4200]$} & [0.2439] & {$[-0.2982]$} & [0.2653] & {$[-0.193]$} \\
\hline \multirow{2}{*}{ BCI } & 0.1376 & 0.3847 b & 0.3427 & $0.3808^{b}$ & 0.3802 & $0.3352^{c}$ & 0.1515 & 0.6099 a \\
\hline & [0.4068] & [2.2218] & [1.0138] & [2.1628] & [1.0936] & [1.8932] & {$[0.3707]$} & [2.9718] \\
\hline \multirow{2}{*}{ INT } & -0.2939 & 0.0668 & -0.0089 & 0.1720 & 0.0156 & 0.2084 & -0.0226 & $0.2355^{c}$ \\
\hline & {$[-1.1218]$} & [0.4981] & {$[-0.0319]$} & [1.1902] & [0.0566] & [1.4897] & {$[-0.0819]$} & {$[1.7000]$} \\
\hline \multirow{2}{*}{ FTSE } & $0.6667 \mathrm{a}$ & 0.0412 & $0.6525^{a}$ & 0.0509 & $0.6052^{a}$ & 0.0105 & $0.6180^{a}$ & -0.0007 \\
\hline & [9.2756] & [1.1211] & [9.1558] & [1.3716] & [8.2559] & [0.2813] & [8.369] & {$[-0.0188]$} \\
\hline \multirow{2}{*}{ GDP } & -0.3407 & $1.8612^{\mathrm{a}}$ & -0.4674 & $1.9500 \mathrm{a}$ & -1.0527 & $1.4505^{\mathrm{a}}$ & -1.2576 & $1.5508^{a}$ \\
\hline & {$[-0.3633]$} & [3.8763] & {$[-0.5069]$} & [4.059] & {$[-1.1139]$} & [3.0142] & {$[-1.3155]$} & [3.2299] \\
\hline \multirow{2}{*}{ REIT(-1) } & 0.0839 & -0.0069 & 0.0542 & -0.0114 & 0.0315 & -0.0307 & 0.0316 & -0.0302 \\
\hline & [1.6183] & {$[-0.2583]$} & [1.0543] & {$[-0.4258]$} & [0.6103] & [-1.1697] & [0.6119] & {$[-1.1667]$} \\
\hline \multirow{2}{*}{ C } & -0.1494 & $-0.3843 b$ & -0.3602 & $-0.3820^{b}$ & -0.3967 & $-0.3341^{c}$ & -0.1655 & $-0.6095^{a}$ \\
\hline & {$[-0.4373]$} & {$[-2.1976]$} & {$[-1.0546]$} & {$[-2.1471]$} & {$[-1.1281]$} & {$[-1.8657]$} & {$[-0.4015]$} & {$[-2.9442]$} \\
\hline Adj. $R^{2}$ & 0.9221 & 0.5014 & 0.9260 & 0.5090 & 0.9282 & 0.5452 & 0.9283 & 0.5581 \\
\hline F-stat & 201.0856 & 17.9916 & 177.1096 & 15.5987 & 157.1299 & 15.4719 & 137.7686 & 14.3409 \\
\hline \multirow{2}{*}{$\begin{array}{l}\text { Residual } \\
\text { serial } \\
\text { correlation: }\end{array}$} & LM test & p-value & LM test & p-value & LM test & p-value & LM test & $\mathrm{p}$-value \\
\hline & 6.0089 & 0.1985 & 6.6897 & 0.1532 & 5.1061 & 0.2766 & 5.0628 & 0.2809 \\
\hline
\end{tabular}

Note: number in [] shows the t-statistic for each coefficient.

a $1 \%$ significance level, b $5 \%$ significance level, c $10 \%$ significance level

The optimal lag period is selected according to VAR lag selection criteria. LM tests report no autocorrelation issues for all models. 
The crisis dummy variable adds another dimension to the findings. The interaction term, which represents the marginal effect of past NAV growth during the crisis, displays a positive coefficient. As above, the positive coefficient is interpreted as indicating overreaction to growth information during this period.

An additional interaction term, CRISIS $* \mathrm{ABOVE} * \mathrm{NAVG}_{\mathrm{t}-1}$, tests for consistency in the reaction to above average growth patterns during the crisis. The significant negative coefficient recorded for the interaction term is in contrast to the results for ABOVE * $\mathrm{NAVG}_{\mathrm{t}-1}$. The result suggests a prediction that the response to positive trends in NAV growth is affected by the crisis, such that the public market displays a significantly negative response (i.e., $-4.616+0.9121=-3.7039$ ) to rising trend in NAV growth in this period, suggesting a underreaction, and then NAV discounts widen substantially.

Our finding is largely in line with existing literature. Easterwood and Nutt (1999)'s generalised optimism concept provides the initial impetus for the focus on series of above average growth information. They contend that investors have a tendency to show greater sensitivity to positive information and are less likely to acknowledge negative information. More recently, it has been suggested that overreaction on the up-side may be a rational response (Gu \& Xue, 2007). Clatworthy, Peel, and Pope (2012) find evidence for asymmetry in the loss functions of stock market analysts and suggest that the lower costs of making positive errors results in more analysts generating optimistic forecasts. To the extent that the optimistic analyst forecasts influence the behavior of investors, an up-side bias in analyst forecasts may also lead to overreaction to positive news in the market, consistent with the findings of Model 2.

In addition to the main findings regarding the hypotheses under investigation, the model specification generates a number of other results that are consistent with existing literature. As expected, in the NAV discount equation, the lagged term is highly significant, representing serial correlation in the series. The model also predicts that the sentiment variable (i.e., BCI) exhibits a significant relationship with the NAV growth, which is interpreted as reflecting the greater sensitivity of the public market valuation to market sentiment. The positive coefficient suggests, an increase in market sentiment is predicted to lead to a greater increase in the public market valuation. This suggests a role for economy-wide sentiment different from the irrational behaviors implied by the hypotheses.

The results of Model 2 thus appear to provide broad support for the adoption of specific behavioral biases in NAV discount models. Our hypotheses, predicting underreaction to isolated information (Hypothesis I) and overreaction to positive momentum, i.e. consecutive past growths (Hypothesis II), are both supported. In the following section, we also investigate two alternative behavioural explanations that may potentially improve the explanatory power of Model 2.

\section{Alternative Behavioral Explanations}

Model 2 focuses on testing overreaction to series of above average NAV growth. However, close examination of the literature reveals mixed results as to whether overreaction 
should be more pronounced to negative or positive information. Stressful situations often trigger coping strategies and 'primitive methods of expression', providing scope for heuristics and myopic behavior during downturns. More recent explanations for overreaction to negative news emphasise the role of reference points. This argument begins by assuming individuals are naturally optimistic, holding a positive reference point. It follows that when negative news arrives, as its distance is further from the reference point than positive news of the same magnitude, it appears worse and attracts an extreme response (Soroka, 2006). Aversion to loss provides a further explanation, which is supported by the consumption dynamics observed in the macro economy.

A. S. Ahmed, Zhang, and Lobo (2000) attempt to replicate the conclusions of Easterwood and Nutt (1999) and identify significant instability in the results, casting doubt on the original research. Overreaction to negative news also seems to be a feature of other national stock markets (A. Ahmed \& Skerratt, 2010). The peculiar characteristics of property companies relative to the rest of the stock market might provide further support for a prediction that overreaction would be more extreme to negative information. The high debt capacity and REIT pay out regulations, which result in a low free cash flow, are among the factors that lead public real estate companies, on average, to be highly levered (Yang, Zhou, \& Leung, 2012). The reduced liquidity, increased likelihood of default, and possibility of fire sales, suggest high gearing may increase investor aversion to negative information.

Model 3 shows the results of an extension to account for an asymmetric response to good and bad news. The extension is made by including an additional dummy variable, BELOW, to enable a comparison between responses to series of high or low NAV growth information. Mimicking the approach taken to represent positive trends, the dummy variable is defined to represent periods in which the two prior periods show below average growth. The estimation results of Model 3 is given in the fourth column in Table 3. However, the coefficient of BELOW $* \mathrm{NAVG}_{\mathrm{t}-1}$ and CRISIS $* \mathrm{BELOW} * \mathrm{NAVG}_{\mathrm{t}-1}$ are insignificant. It follows that the results appear to support the original model specification (i.e., Model 2), which focused on investigating overreaction to series of above average growth information.

A further possible nuance in the relationship is related to the concept of cognitive dissonance (Festinger, 1962). Antoniou, Doukas, and Subrahmanyam (2013) suggest that the severity of behavioral biases is related to the broader economic sentiment. They argue that a combination of contradictory information has the effect of muting behavioral biases; if information is received contrary to the sentiment held at the time, it will receive less attention and underreaction is more likely to be observed.

We estimate Model 4 to incorporate the effect of cognitive dissonance. Two additional dummy variables are defined to reflect categories of investor sentiment. Investors are categorised as pessimistic (PESS) when the business confidence index value is in the lower quartile of the series and optimistic (OPT) when business confidence is recorded in the upper quartile. The investor sentiment categories are interacted with the opposing trend variable for NAV growth information; the pessimistic variable is interacted with the above average run of NAV growth and the optimistic variable is interacted with the below 
average run of NAV growth. The explanation of Antoniou et al. (2013) suggest that underreaction is expected to be most pronounced during optimistic conditions due to limited arbitrage activity as a result of increased costs of short selling. However, the coefficient estimate of $\mathrm{OPT} * \mathrm{BELOW} * \mathrm{NAVG}_{\mathrm{t}-1}$ is insignificant. This alternative explanation is not supported by our data.

\section{Conclusions}

Through the adoption of an explicit behavioral approach to the NAV discount model, this paper contributes to the explanations for the NAV discount puzzle. Using EPRA/NAREIT UK data between 2002 and 2017, our analysis suggests causality from information in private real estate market (NAV growth) to public real estate market (NAV discount). Evidence is found for biased reactions of public market to fundamental information in the private market, i.e., negative causality of NAV growth highlights underreaction to isolated information and implication of dummy variable and their interaction demonstrate overreaction to series of good news.

In addition to its contribution to the NAV discount literature, the findings of this paper have broader implications. The bursting of the property market bubble during the Global Financial Crisis is a dramatic illustration of the impact of real estate investor behavior on the wider economy. It follows that how to dissolve real estate bubbles in the future is of grave concern to policy makers. This paper highlights the significant challenges faced by those designing policy for such a complex market. It is often suggested that improving information available to investors would reduce the tendency for prices to diverge from fundamentals (Graff \& Young, 1997). However, the discussion in this paper suggests that such a strategy may be misguided if an overwhelming volume of information serves to promote heuristics that contribute to market distortions. Furthermore, the findings suggest that biases tie together the public and private market and that the feedback effects from each market may perpetuate cyclical tendencies.

There is much scope for more detailed research of the market and its nuances. For instance, there has been some indication that the public real estate market might be considered in terms of liquidity classes, in order to improve understanding of movements of capital among REITs in accordance with the 'flight to liquidity theory' (P. K. Das, J. Freybote, \& G. Marcato, 2015). Sectors of the US market (i.e. apartment, retail, office) have also been considered to display different public/private market behaviors (Hoesli, Oikarinen, \& Serrano, 2015), but this is yet to be considered for the UK. Such work may be followed by research investigating whether the results can be replicated in overseas markets, where cultural factors may mitigate or exaggerate the existence of certain biases. While research in this area is still emerging, the fundamental insight is the emphasis that investors do not operate in isolation, but rather are part of the broader real estate system, engaging with the other sides of the market and market participants. The impossibility of isolating one market from another seems to present the opportunity for the transmission of information and sentiment to operate in all manner of directions. 


\section{References}

Ahmed, A., \& Skerratt, L. (2010). How markets react to earnings announcements in the absence of analysts and institutions: evidence from the Saudi market. International Journal of Monetary Economics and Finance, 3(4), 338-358.

Ahmed, A. S., Zhang, X.-h., \& Lobo, G. J. (2000). Do analysts under-react to bad news and over-react to good news? Available at SSRN 253889.

An, H., Wu, Q., \& Wu, Z. (2015). REIT Crash Risk and Institutional Investors. The Journal of Real Estate Finance and Economics, 1-32.

Andreassen, P. B. (1990). Judgmental extrapolation and market overreaction: On the use and disuse of news. Journal of Behavioral Decision Making, 3(3), 153-174.

Andreassen, P. B., \& Kraus, S. J. (1990). Judgmental extrapolation and the salience of change. Journal of Forecasting, 9(4), 347-372.

Antoniou, C., Doukas, J. A., \& Subrahmanyam, A. (2013). Cognitive dissonance, sentiment, and momentum. Journal of Financial and Quantitative Analysis, 48(01), 245-275.

Antwi, A., \& Henneberry, J. (1995). Developers, non-linearity and asymmetry in the development cycle. Journal of Property Research, 12(3), 217-239.

Baker, M., \& Wurgler, J. (2006). Investor sentiment and the cross-section of stock returns. Journal of Finance, 61(4), 1645-1680.

Bao, H. X. H., \& Li, S. H. (2016). Overconfidence and Real Estate Research: A Survey of the Literature. Singapore Economic Review, 61(4).

Bao, H. X. H., \& Meng, C. C. (2017). Loss Aversion and Housing Studies. Journal of Real Estate Literature, 25(1), 49-75.

Barberis, N., Shleifer, A., \& Vishny, R. (1998). A model of investor sentiment. Journal of Financial Economics, 49(3), 307-343.

Barkham, R. J., \& Ward, C. W. R. (1999). Investor Sentiment and Noise Traders: Discount to Net Asset Value in Listed Property Companies in the U.K. [Article]. Journal of Real Estate Research, 18(2), 291.

Benveniste, L., Capozza, D. R., \& Seguin, P. J. (2001). The value of liquidity. Real Estate Economics, 29(4), 633-660.

Bernard, V. L., \& Thomas, J. K. (1990). Evidence that stock prices do not fully reflect the implications of current earnings for future earnings. Journal of Accounting and Economics, 13(4), 305-340.

Bond, S., \& Shilling, J. (2003). An evaluation of property company discounts in Europe. working paper, EPRA, University of Cambridge, Cambridge. .

Bordalo, P., Gennaioli, N., \& Shleifer, A. (2015). Competition for attention. The Review of Economic Studies, 83(2), 481-513.

Brounen, D., \& Laak, M. (2005). Understanding the discount: Evidence from European property shares. Journal of Real Estate Portfolio Management, 11(3), 241-251.

Brown, G. R., \& Matysiak, G. A. (2000). Real estate investment : a capital market approach. Harlow, Grande-Bretagne: Financial Times Prentice Hall.

Capozza, D., \& Korean, S. (1995). Property Type, Size and REIT Value. Journal of Real Estate Research, 10(4), 363-379.

Capozza, D., \& Korean, S. (2009). Property type, size and REIT value. Journal of Real Estate Research.

Case, K. E., \& Shiller, R. J. (1988). The behavior of home buyers in boom and post-boom markets. New England Economic Review(Nov), 29-46.

Chen, N. F., Kan, R., \& Miller, M. H. (1993). Are the Discounts on Closed-End Funds a Sentiment Index? The Journal of Finance, 48(2), 795-800. 
Cherkes, M., Sagi, J., \& Stanton, R. (2009). A Liquidity-Based Theory of Closed-End Funds. Review of Financial Studies, 22(1), 257-297.

Cheung, W. M., Chung, R., \& Fung, S. (2015). The effects of stock liquidity on firm value and corporate governance: Endogeneity and the REIT experiment. Journal of Corporate Finance, 35, 211-231.

Clatworthy, M. A., Peel, D. A., \& Pope, P. F. (2012). Are analysts' loss functions asymmetric? Journal of Forecasting, 31(8), 736-756.

Clayton, J., \& MacKinnon, G. (2001). Explaining departures from NAV in REIT pricing: noise or information? : working paper, University of Cincinnati, Cincinnati, $\mathrm{OH}$.

Clayton, J., \& MacKinnon, G. (2002). Departures from NAV in REIT pricing: The private real estate cycle, the value of liquidity and investor sentiment. Real Estate Research Institute, Working Paper.

Daniel, K., Hirshleifer, D., \& Subrahmanyam, A. (1998). Investor psychology and security market under-and overreactions. The Journal of Finance, 53(6), 1839-1885.

Daniel, K., \& Titman, S. (2006). Market Reactions to Tangible and Intangible Information. The Journal of Finance, 61(4), 1605-1643.

Das, Freybote, \& Marcato. (2015). An Investigation into Sentiment-Induced Institutional Trading Behavior and Asset Pricing in the REIT Market. Journal of Real Estate Finance and Economics, 51(2), 160-189.

Das, P. K., Freybote, J., \& Marcato, G. (2015). An investigation into sentiment-induced institutional trading behavior and asset pricing in the REIT market. The Journal of Real Estate Finance and Economics, 51(2), 160-189.

De Bondt, W. F., \& Thaler, R. (1985). Does the stock market overreact. Paper presented at the Journal of Finance.

De Long, J. B., Shleifer, A., Summers, L. H., \& Waldmann, R. J. (1990). Noise trader risk in financial markets. Journal of political Economy, 703-738.

DeCoster, G. P., \& Strange, W. C. (2012). Developers, Herding, and Overbuilding. Journal of Real Estate Finance and Economics, 44(1-2), 7-35.

Easterwood, J. C., \& Nutt, S. R. (1999). Inefficiency in analysts' earnings forecasts: Systematic misreaction or systematic optimism? The Journal of Finance, 54(5), 1777-1797.

Elton, E. J., Gruber, M. J., \& Busse, J. A. (1998). Do Investors Care about Sentiment? The Journal of Business, 71(4), 477-500.

Festinger, L. (1962). A theory of cognitive dissonance (Vol. 2): Stanford university press.

Freybote, J., \& Seagraves, P. A. (2017). Heterogeneous Investor Sentiment and Institutional Real Estate Investments. Real Estate Economics, 45(1), 154-176.

Geltner, D. (1993). Estimating Market Values for Appraised Values without Assuming an Efficient Market. Journal of Real Estate Research, 8(3).

Geltner, D. (2015). Real Estate Price Indices and Price Dynamics: An Overview from an Investments Perspective. Annual Review of Financial Economics, 7(1), 615-633.

Geltner, D., G., N., Clayton, J., \& Eichholtz, P. (2013). Commercial real estate analysis and investments (2nd ed.). Mason, Ohio: Thompson South-Western.

Glascock, J. L., Lu, C. L., \& So, R. W. (2000). Further evidence on the integration of REIT, bond, and stock returns. Journal of Real Estate Finance and Economics, 20(2), 177194.

Graff, R. A., \& Young, M. S. (1997). Serial Persistence in Equity REIT Returns. Journal of Real Estate Research, 14(3), 183-214.

$\mathrm{Gu}, \mathrm{Z} ., \quad \&$ Xue, J. (2007). Do analysts overreact to extreme good news in earnings? [journal article]. Review of Quantitative Finance and Accounting, 29(4), 415-431. 
Gyourko, J., \& Keim, D. B. (1992). What does the stock market tell us about real estate returns? Real Estate Economics, 20(3), 457-485.

Hoesli, M., Oikarinen, E., \& Serrano, C. (2015). Do Public Real Estate Returns Really Lead Private Returns? The Journal of Portfolio Management, 41(6), 105-117.

Ikenberry, D. L., \& Ramnath, S. (2002). Underreaction to self-selected news events: The case of stock splits. Review of Financial Studies, 15(2), 489-526.

Jandl, J.-O. (2015). Information Processing and Stock Market Volatility-Evidence from Real Estate Investment Trusts. Americas Conference on Information Systems 2015.

Jegadeesh, N., \& Titman, S. (1993). Returns to buying winners and selling losers: Implications for stock market efficiency. The Journal of Finance, 48(1), 65-91.

Kadiyala, P., \& Rau, P. R. (2004). Investor Reaction to Corporate Event Announcements: Underreaction or Overreaction? The Journal of Business, 77(2), 357-386.

Lee, C., Shleifer, A., \& Thaler, R. H. (1991). Investor sentiment and the closed-end fund puzzle. The Journal of Finance, 46(1), 75-109.

Lee, C. M. C., Shleifer, A., \& Thaler, R. H. (1991). Investor Sentiment and the Closed-End Fund Puzzle. Journal of Finance, 46(1), 75-109.

Lenkey, S. L. (2015). The closed-end fund puzzle: Management fees and private information. Journal of Financial Intermediation, 24(1), 112-129.

Li, J., Mooradian, R. M., \& Yang, S. X. (2009). The Information Content of the NCREIF Index. Journal of Real Estate Research, 31(1), 93-116.

Liow, K. H. (1996). Property companies' share price discounts and property market returns The Singapore evidence. Journal of Property Finance, 7(4), 64-77.

Malkiel, B. G. (1995). The Structure of Closed-End Fund Discounts Revisited. Journal of Portfolio Management, 21(4), 32-38.

Morri, G., \& Baccarin, A. (2016). European REITs NAV discount: do investors believe in property appraisal? Journal of Property Investment \& Finance, 34(4), 347-374.

Morri, G., McAllister, P., \& Ward, C. (2005). Explaining deviations from NAV in UK property companies: rationality and sentimentality. working paper, presented at 12th ERES Annual Meeting, Dublin.

Pattitoni, P., Petracci, B., \& Spisni, M. (2013). NAV discount in REITs: the role of expert assessors. Applied Economics Letters, 20(2), 194-198.

Ramiah, V., Xu, X. M., \& Moosa, I. A. (2015). Neoclassical finance, behavioral finance and noise traders: A review and assessment of the literature. International Review of Financial Analysis, 41, 89-100.

Rehkugler, H., Schindler, F., \& Zajonz, R. (2012). The net asset value and stock prices of European real estate companies. In W. Breuer \& C. Nadler (Eds.), Real Estate Finance (pp. 53-77). Wiesbaden: Gabler Verlag.

Shefrin, H. (2013). Asset Pricing and Behavioural Finance Portfolio theory and management (pp. xxxii, 767 p.). New York: Oxford University Press.

Soroka, S. N. (2006). Good News and Bad News: Asymmetric Responses to Economic Information. Journal of Politics, 68(2), 372-385.

Tetlock, P. C. (2007). Giving content to investor sentiment: The role of media in the stock market. The Journal of Finance, 62(3), 1139-1168.

Tversky, A., \& Kahneman, D. (1974). Judgment under Uncertainty - Heuristics and Biases. Science, 185(4157), 1124-1131.

Wameryd, K.-E. (2001). Stock-market psychology: How people value and trade Stocks. Northampton. USA: MA: Edward Elgar.

Wang, Z. Y., \& Hui, E. C. M. (2017). Fundamentals and Market Sentiment in Housing Market. Housing Theory \& Society, 34(1), 57-78. 
Yang, J., Zhou, Y., \& Leung, W. K. (2012). Asymmetric Correlation and Volatility Dynamics among Stock, Bond, and Securitized Real Estate Markets. [journal article]. The Journal of Real Estate Finance and Economics, 45(2), 491-521.

Yavas, A., \& Yildirim, Y. (2011). Price discovery in real estate markets: A dynamic analysis. The Journal of Real Estate Finance and Economics, 42(1), 1-29.

\section{Acknowledgement:}

We thank Martin Allen for his presentation at the Real Estate Investment and Finance Seminar (Michaelmas Term 2015), Department of Land Economy, University of Cambridge. His ideas and insights shared during this seminar have provided the basis for the subsequent research undertaken in this paper. We are also grateful for Eva Steiner's advice during the initial stages of the project. 